\title{
A critical role of PUMA in maintenance of genomic integ- rity of murine spermatogonial stem cell precursors after genotoxic stress
}

\author{
Anne Forand ${ }^{1,2,3}$, J Bernardino-Sgherri ${ }^{1,2,3}$ \\ ${ }^{I}$ CEA, DSV, iRCM, SCSR, Laboratory of Differentiation and Radiobiology of the Gonads, Fontenay aux Roses F-92265, France; \\ ${ }^{2}$ Université Paris 7 Denis Diderot, Unit of Gametogenesis and Genotoxicity, Fontenay aux Roses F-92265, France; ${ }^{3}$ INSERM, \\ U566, Fontenay aux Roses F-92265, France
}

Neonatal gonocytes are precursors of spermatogonial stem cells. Preserving their integrity by elimination of damaged germ cells may be crucial to avoid the transmission of genetic alterations to progeny. Using $\gamma$-irradiation, we investigated by immunohistochemistry, flow cytometry and real-time PCR components of the death machinery in neonatal gonocytes. Their death was correlated with caspase 3 activation but not with AIF translocation into the nucleus. The in vivo contribution of both the extrinsic and the intrinsic pathways was then investigated. We focused on the roles of TRAIL/Death Receptor 5 (DR5) and PUMA. Our results were validated using knockout mice. Whereas DR5 expression was upregulated at the cell surface after radiation, caspase 8 was not activated. However, we detected caspase 9 cleavage associated with cytochrome $c$ release. In mice deficient for PUMA, radiation-induced gonocyte apoptosis was reduced, whereas invalidation of TRAIL had no effect. Overall, our results show that genotoxic stressinduced apoptosis of gonocytes is caspase-dependent and involves almost exclusively the intrinsic pathway. Furthermore, PUMA plays a critical role in the maintenance of genomic integrity of spermatogonial stem cell precursors.

Keywords: cell death, gonocyte, PUMA, apoptosis, caspase, radiation

Cell Research (2009) 19:1018-1030. doi: 10.1038/cr.2009.50; published online 5 May 2009

\section{Introduction}

Apoptosis is a physiological process essential for the development and maintenance of tissue homeostasis in multicellular organisms. Apoptosis is characterised by a series of typical morphological and biochemical changes [1]. Caspase activation depends mainly on two well-defined pathways, the extrinsic and intrinsic pathways. The extrinsic pathway is triggered by the binding of specific extracellular ligands to their transmembrane death receptors to promote cell death. Three main pairs of coupled ligand/receptors are found in mammals: TNF $\alpha /$ TNFR1, FASL/FAS and TRAIL (also known as TNFSF10)/ Death Receptor 5 (DR5, also known as TNFRSF10B) [2]. Ligand binding leads to caspase 8 recruitment [3,

Correspondence: J Bernardino-Sgherri

Tel: +33 1465480 04; Fax: +33146549906

E-mail: jacqueline.bernardino@cea.fr

Received 9 September 2008; revised 12 January 2009; accepted 3 March 2009; published online 5 May 2009
4] and activation [5, 6]. Active caspase 8 could then proteolytically activate execution caspases 3 and 7 [7]. These executioners cleave downstream targets, leading to death. This pathway could be regulated by c-FLIP (also known as CFLAR) [8], which is a caspase-8-like protein without catalytic activity [9]. c-FLIP L $_{\text {could prevent or }}$ enhance caspase 8 activation according to its intracellular concentrations [10]. The intrinsic pathway is activated in response to cellular stress or DNA damage. This pathway is characterised by cytochrome $c$ release from mitochondria after BAX/BAK activation [11] and caspase 9 cleavage. In turn, caspase 9 activates caspases 3 and 7 to propagate the proteolytic cascade [12]. This pathway is regulated by the BCL2 family members, some of which are transcriptionally regulated by p53 (also known as TRP53) [13], in particular the BH3-only protein, PUMA (also known as BBC3).

Cell death can also be provoked by a caspase-independent pathway involving AIF (also known as AIFM1). AIF is a mitochondrial protein which can translocate 
from the mitochondria to the nucleus to elicit pro-apoptotic effects [14]. AIF is believed to induce cell death by binding to DNA [15], stimulating DNase activity and triggering chromatin condensation and DNA loss associated with large-scale fragmentation [14].

Apoptosis is an important physiological process in the developing testis since it regulates the germ cell/Sertoli cell ratio, ensuring a delicate balance required for efficient spermatogenesis and fertility [16]. Spermatogenesis is a continuous process that begins during foetal life and continues throughout adulthood. During gonad formation, primordial germ cells differentiate into gonocytes that proliferate for a few days and then arrest in the $\mathrm{G}_{0} /$ $\mathrm{G}_{1}$ phase of the cell cycle. Gonocytes resume mitosis after birth to differentiate into spermatogonial stem cells and type A spermatogonia [17]. Germ cell differentiation coincides with two peaks of apoptosis during foetal (12.5-15.5 days post coitum - dpc) and postnatal life (10-13 days post partum - dpp) [18], which involve both the intrinsic $[16,19,20]$ and extrinsic pathways [21].

In stress conditions, Sertoli cell injury by MEHP (mono-(2-ethylhexyl)phthalate) induces germ cell death by activating the extrinsic pathway [22]. Furthermore, heat, which affects both Sertoli and germ cells directly, kills germ cells via the intrinsic pathway [23]. Radiosensitivity of germ cells depends on their developmental stage [24-26]. Effects of genotoxic stress have mainly been studied in adult spermatogonia and depend on p53 status [27, 28]. p53-dependent upregulation of Fas has been described after irradiation [29]. However, in contrast to adult spermatogonia, FAS is weakly expressed in neonatal testis and FASL was not detected [18]. TRAIL and its receptor, DR5, have been shown to be expressed in rodent and human adult germ cells [30, 31]. Although TRAIL/DR5 has been implicated in spermatocyte apoptosis induced by MEHP exposure [32], its role after irradiation has not been investigated.

Since neonatal germ cells, i.e., gonocytes, are the precursors of spermatogonial stem cells [17], preserving their integrity by elimination of severely damaged cells is crucial for fertility in adulthood and for avoiding transmission of genetic alterations [33]. To clarify the molecular components of the death machinery within the neonatal germ cells, we sought to analyse in vivo the contribution of both the intrinsic and extrinsic pathways after irradiation. We focused on the study of TRAIL/ DR5 and PUMA, which have been shown to be involved in radiation-induced cell death of somatic cell types [34, 35], and we validated our results using Trail and Puma KO mice. We found that the caspase-dependent pathway, but not AIF-mediated apoptosis, is activated almost exclusively through the intrinsic pathway. Results from
$\mathrm{KO}$ mice reveal a major role for PUMA in the regulation of genotoxic stress-induced apoptotic response of gonocytes.

\section{Results}

Ionising radiation greatly reduces testicular germ cell number

The effect of ionising radiation on the neonatal testis was analysed by counting the number of remaining germ cells after whole-body exposure of NMRI mice to a dose of 2 Gy (Figure 1A and 1B). At 1 dpp, only $23 \% \pm 11.4 \%$ of germ cells are committed to S-phase as indicated by the phosphorylation of pRB in these cells [36]. Therefore, at the time of irradiation, almost all germ cells were gonocytes.

Whereas germ-cell number was not affected $10 \mathrm{~h}$ after irradiation, it was dramatically decreased (by $70 \%$ ) at 24 h compared with that of the control $(P<0.05)$. At $48 \mathrm{~h}$, germ-cell number in irradiated testes was still lower than that in the control $(P<0.05)$ and similar to that of the 24-h time point. $96 \mathrm{~h}$ after irradiation, germ-cell number was increased compared with that at $48 \mathrm{~h}(P<0.05)$, but it remained lower than that in the control. Altogether, these results show that $\gamma$-radiation greatly reduces gonocyte number after irradiation.

\section{Death of gonocytes involves caspase 3 activation}

To determine if germ-cell number decrease was caused by apoptosis, we measured the percentage of cleaved caspase 3-positive gonocytes (Figure 1C) by immunohistochemistry (Figure 1B and Supplementary information, Figure S1), at the same time points when germ cells were counted.

$10 \mathrm{~h}$ after irradiation, the percentage of gonocytes positive for cleaved caspase 3 was increased compared with that in the control $(P<0.05) .24 \mathrm{~h}$ after exposure, the percentage of such positive cells increased 2.9-fold $(P<$ 0.05 ) versus that after $10 \mathrm{~h}$; it stayed steady for the next $24 \mathrm{~h}$, and then dropped sharply at $96 \mathrm{~h}$, but remained higher than that in the control $(P<0.05)$. DNA fragmentation was confirmed $24 \mathrm{~h}$ after irradiation $(P<0.05)$ using in situ end-labelling (ISEL) (Figure 1D). Thus, increase in caspase 3 cleavage and in ISEL-positive cells was correlated with a decrease in germ-cell number, suggesting that gonocytes are eliminated by caspasedependent apoptosis after irradiation.

Radiation-induced apoptosis in gonocytes is accompanied by caspase activation

To confirm that gonocyte apoptosis was dependent on caspase activation, we performed the same experiments 
A

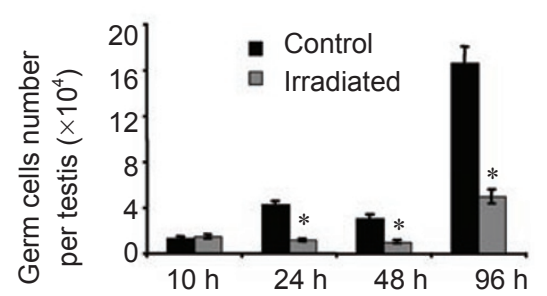

C

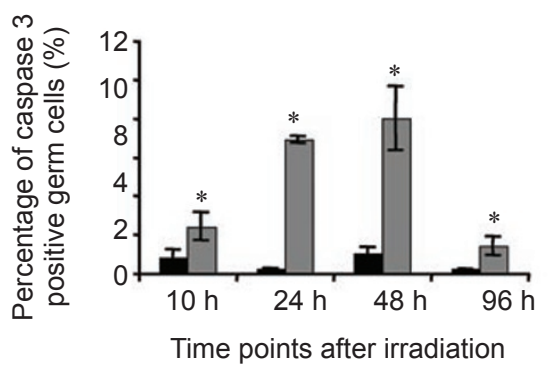

B

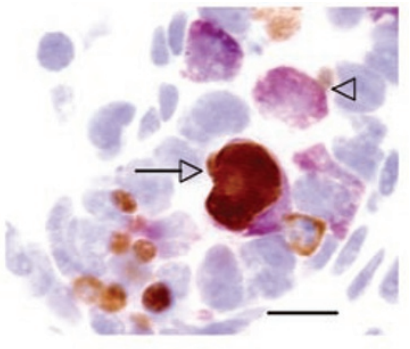

D

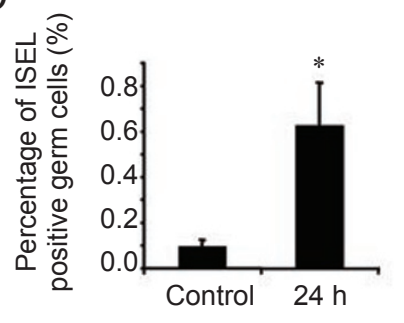

Figure 1 Analysis of germ-cell number and caspase 3 activation after irradiation of 1-day-old mice. Means \pm SEM of at least three experiments are presented per experimental condition. (A) Analysis of germ-cell number. Each time point (grey bar) is compared with the appropriate control (black bar) (i.e., $1 \mathrm{dpp}+10 \mathrm{~h}, 1 \mathrm{dpp}+24 \mathrm{~h}$ etc.). (B) Double staining MVH/cleaved caspase 3. Germ cells are identified with MVH staining (purple) (arrow heads), and apoptotic germ cells with cleaved caspase 3 (brown) are indicated by an arrow. Bar $=10 \mu \mathrm{m}$. (C) Analysis of cleaved caspase 3-positive germ-cell percentage. Each time point (grey bar) is compared with the appropriate control (black bar) (i.e., $1 \mathrm{dpp}+10 \mathrm{~h}, 1 \mathrm{dpp}+24 \mathrm{~h}$, etc.). (D) Analysis of in situ end labelling (ISEL)-positive germ-cell percentage $24 \mathrm{~h}$ after irradiation. Significant differences from the control are indicated $\left({ }^{*} P<0.05\right)$.

after in vivo injection of z-VAD-fmk, a pan-caspase inhibitor (Figure 2).

At the concentration used, DMSO did not have any adverse effect on germ-cell survival and caspase 3 activation (compare Irr + PBS and Irr + DMSO in Figure 2, $P=0.8$ ). Irradiated NMRI mice treated with $\mathrm{z}$-VAD-fmk showed a higher germ-cell number compared with that in the irradiated control, although the difference did not reach statistical significance $(P=0.08)$. Irradiated NMRI mice treated with $\mathrm{z}$-VAD-fmk showed no significant decrease in germ-cell number compared with that in the irradiated control. Analysis of the percentage of cleaved caspase 3-positive gonocytes showed a substantial increase in irradiated DMSO-treated mice $(P=0.006)$ (Figure $2 \mathrm{~B})$. Z-VAD-fmk-treated mice exhibited a percentage of active caspase 3 -positive germ cells $(1.17 \% \pm 0.26 \%)$ that was higher than that in control mice $(0.45 \% \pm 0.08 \%$; $P=0.01$ ), but lower than that in irradiated DMSOtreated mice $(2.23 \% \pm 0.39 \% ; P \leq 0.05)$. These results indicate that $\mathrm{z}$-VAD-fmk inhibits caspase 3 cleavage. Taken together, these data suggest that caspase activation is involved in radiation-induced gonocyte apoptosis.

The AIF-mediated caspase-independent pathway is not involved in gonocyte apoptosis

To determine if the caspase-independent pathway was also activated after irradiation in gonocytes, we used immunohistochemistry to look for translocation of AIF from the mitochondria to the nucleus (Figure 3 ).

We observed AIF cytoplasmic staining in gonocytes of control testes (not shown). This staining was granular and corresponded to mitochondrial localisation. The same staining was observed in gonocytes of irradiated NMRI mice, suggesting that AIF is not released from mitochondria after irradiation (Figure 3A).

In addition, AIF localisation was studied in gonocytes after irradiation of mice pre-treated with z-VAD, in order to determine if the caspase-independent pathway could be activated when caspase activation was inhibited. We found no localisation of AIF in the nucleus, indicating that the caspase-independent pathway does not compensate for inhibition of caspase activation (Figure 3B).

\section{Radiation enhances Ser15-p53 phosphorylation and up-} regulates $p 53$ target genes in the testis

We first looked for activation of $\mathrm{p} 53$, a key protein that transcriptionally regulates target genes involved in the two major apoptotic pathways (intrinsic and extrinsic) (Figure 4).

Immunohistochemistry for phospho-Ser15-p53 revealed the presence of phosphorylated p53 in gonocyte nuclei $10 \mathrm{~h}$ after irradiation (Figure 4A). Staining was 


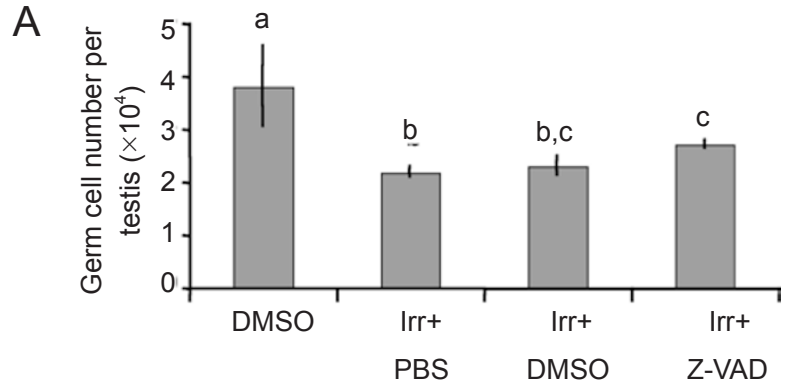

B

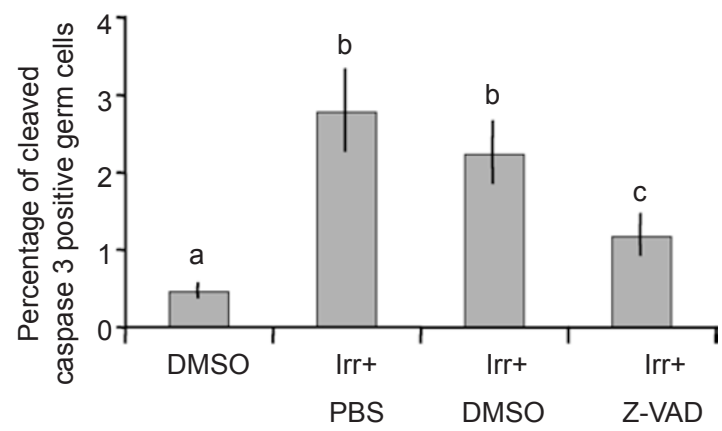

Figure 2 Effect of the pan-caspase inhibitor, z-VAD-fmk, on gonocyte apoptosis induced by irradiation. Mice were injected with z-VAD at $100 \mathrm{mg} / \mathrm{kg} 1 \mathrm{~h}$ before irradiation (Irr) and killed $24 \mathrm{~h}$ later. Controls were obtained by DMSO or PBS injection. Means \pm SEM of at least three experiments are presented. (A) Analysis of germ-cell number. (B) Analysis of cleaved caspase 3-positive germ-cell percentage. Superscripts are different when values between experimental conditions are significantly different $(P<0.05)$.

also observed in Sertoli cell nuclei. To confirm p53 involvement in radiation-induced gonocyte apoptosis, we analysed the effect of pifithrin $\alpha$, an inhibitor of p53 transcriptional activity $[37,38]$. We counted the number of germ cells remaining after in vivo injection of pifithrin $\alpha$ and whole-body radiation exposure of NMRI mice at a dose of 2 Gy (Figure 4B). The decrease in germ-cell number seemed to be less severe after injection of pifithrin $\alpha$ compared with untreated irradiated control (Figure 4B, upper graph). Moreover, the percentage of gonocytes positive for cleaved caspase 3 decreased significantly (from $2.6 \% \pm 0.6 \%$ to $1.3 \% \pm 0.2 \% ; P<0.05$ ) when mice were pre-treated with pifithrin $\alpha$ compared with that in irradiated mice pre-treated with DMSO (Figure 4B, lower graph). Taken together, these results suggest a role for $\mathrm{p} 53$ in radiation-induced apoptosis of gonocytes.

Next, we investigated by real-time PCR the expression of selected apoptotic genes, known to be regulated by p53 [13], 6 and $12 \mathrm{~h}$ after irradiation, in germ cellenriched populations (Figure 5A). $12 \mathrm{~h}$ after irradiation all tested genes, except $B c l-X_{L}$ (known as $B c l 2 c l_{L}$ ), were
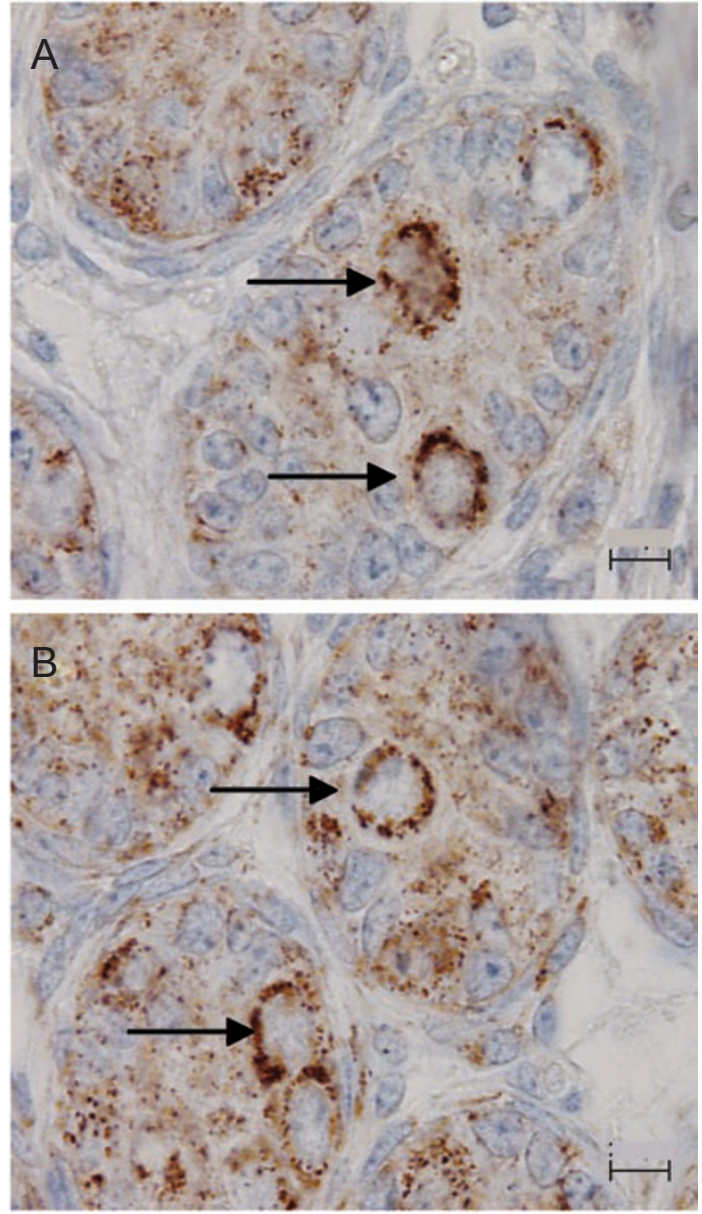

Figure 3 Testis localisation of AIF by immunohistochemistry after irradiation or after z-VAD-fmk treatment. Sections from irradiated mice pre-treated with DMSO $(A)$ and z-VAD-fmk (B) are stained with AIF antibody (brown staining). Sections were counterstained with haematoxylin. AIF is strongly expressed in gonocytes (arrows) of $1 \mathrm{dpp}$ mice and localised in mitochondria in irradiated mice (A), even after z-VAD-fmk pre-treatment (B). Bar $=10 \mu \mathrm{m}$.

upregulated compared with those in the control $(P<0.05)$. Indeed, whereas $B c l-X_{L}$ was upregulated $6 \mathrm{~h}$ after irradiation, its expression was not significantly changed at the 12-h time point after treatment compared with that in the control. In vivo pre-treatment with pifithrin $\alpha$ decreased the expression of Puma by 2.45 -fold after irradiation $(P<0.05)$ (Figure 5B). In contrast, Trp53 expression remained largely unchanged, consistent with cell-type specificity of $\mathrm{p} 53$ as a regulator of its own transcription [39]. Altogether, these results support p53 dependency of gonocyte apoptosis induced by radiation.

Because RT-PCR experiments were performed on germ cell-enriched populations that also contained somatic cells, the results obtained are only suggestive of candidate genes involved in gonocyte radiation-induced 

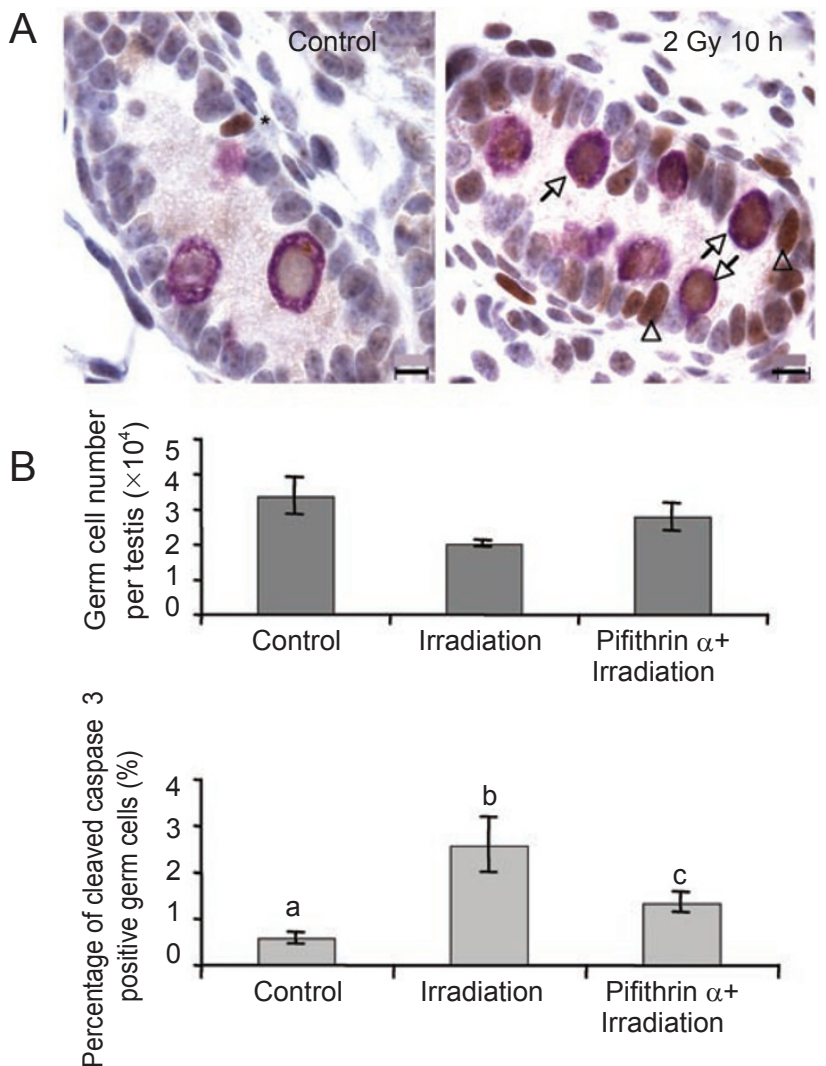

Figure 4 Analysis of p53 phosphorylation and inhibition of p53 transcriptional activity with pifithrin $\alpha$. (A) Immunohistochemical analysis of Ser15-p53 phosphorylation. Sections of control (left) and irradiated (right) testis are stained with a phospho-Ser15p53 antibody (brown staining). Germ cells are identified with an MVH antibody (purple staining). Only a few nuclei are stained in the control (asterisk), whereas numerous nuclei of gonocytes (arrows) and Sertoli cells (arrow heads) are stained in irradiated testis. Bar $=10 \mu \mathrm{m}$. (B) Effect of the p53 transcriptional activity inhibitor, pifithrin $\alpha$, on gonocyte apoptosis induced by irradiation. Mice were injected with pifithrin $\alpha$ (Sigma) at $10 \mathrm{mg} / \mathrm{kg} 1 \mathrm{~h}$ before and $12 \mathrm{~h}$ after irradiation at a dose of $2 \mathrm{~Gy}$, and killed $24 \mathrm{~h}$ after irradiation. Control mice were injected with DMSO. Means \pm SEM of at least three experiments are presented. Upper graph: analysis of germ-cell number. Lower graph: analysis of cleaved caspase 3-positive germ-cell percentage. Superscripts are different when values between experimental conditions are significantly different $(P<0.05)$.

apoptosis. Since Fas seems not to have a major role in radiation-induced apoptosis in adult testis [22, 29], we focused our study on DR5 for the extrinsic pathway, and on PUMA for the intrinsic pathway.

DR5 protein is upregulated at the gonocyte surface after irradiation

To investigate the extrinsic pathway, we analysed DR5 protein expression in gonocytes by flow cytometry (Figure 6).

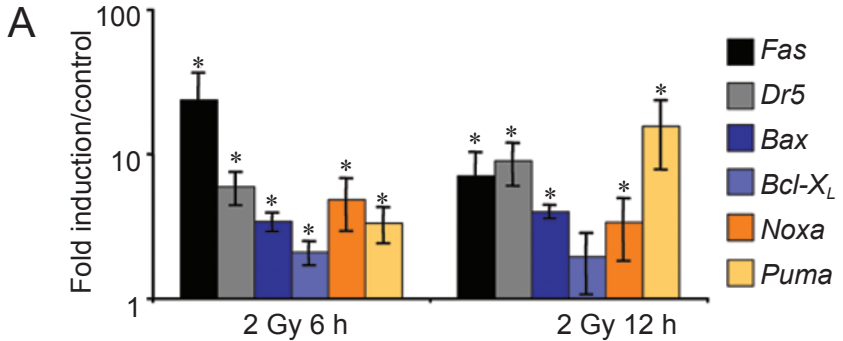

B

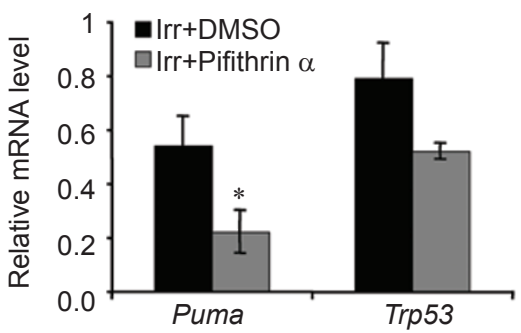

Figure 5 Analysis of p53 transcriptional regulation after irradiation with or without in vivo treatment with pifithrin $\alpha$. (A) Transcriptional regulation of selected apoptotic genes after irradiation. Quantitative PCR was performed on germ cell-enriched populations 6 and $12 \mathrm{~h}$ after irradiation. Actb was used as reference. (B) Transcriptional regulation of Puma and Trp53 after in vivo injection of pifithrin $\alpha$. Pifithrin $\alpha$ was injected a dose of $10 \mathrm{mg} / \mathrm{kg} 1 \mathrm{~h}$ before irradiation, and mice were killed $6 \mathrm{~h}$ later. Control mice were injected with DMSO, and Actb was used as reference. Means \pm SEM of three experiments are presented. Significant differences from controls are indicated $\left({ }^{*} P<\right.$ 0.05).

All gonocytes of NMRI control mice expressed DR5 at their cell surface. However, 12 and $24 \mathrm{~h}$ after irradiation, a two-fold increase in fluorescence intensity was observed $(2 \pm 0.46$ at $12 \mathrm{~h}$ and $1.74 \pm 0.25$ at $24 \mathrm{~h} ; P<$ $0.05)$, indicating an increase in the receptor number at the surface of gonocytes for $20-30 \%$ of the cells (Figure $6)$.

No involvement of the extrinsic pathway in radiationinduced germ cell apoptosis

Since DR5 was upregulated, we next investigated caspase 8 activation by flow cytometry, in order to determine the function of the extrinsic pathway (Figure 7). Assays were performed 1, 3, 5, 7, 12 and $24 \mathrm{~h}$ after irradiation, but no caspase 8 activation was detected.

We asked whether $c$-Flip might be involved in regulation of the gonocyte response to radiation and could be regulated at the mRNA or protein level. Consistent with Giampetri et al. [40], we found strong expression of the c-FLIP protein restricted to gonocytes (not shown). Quantitative PCR on gonocyte-enriched populations, using mouse vasa homologue $(M v h)$ (also known as $D d x 4$ ) as a reference, revealed no change in the c-Flip mRNA 


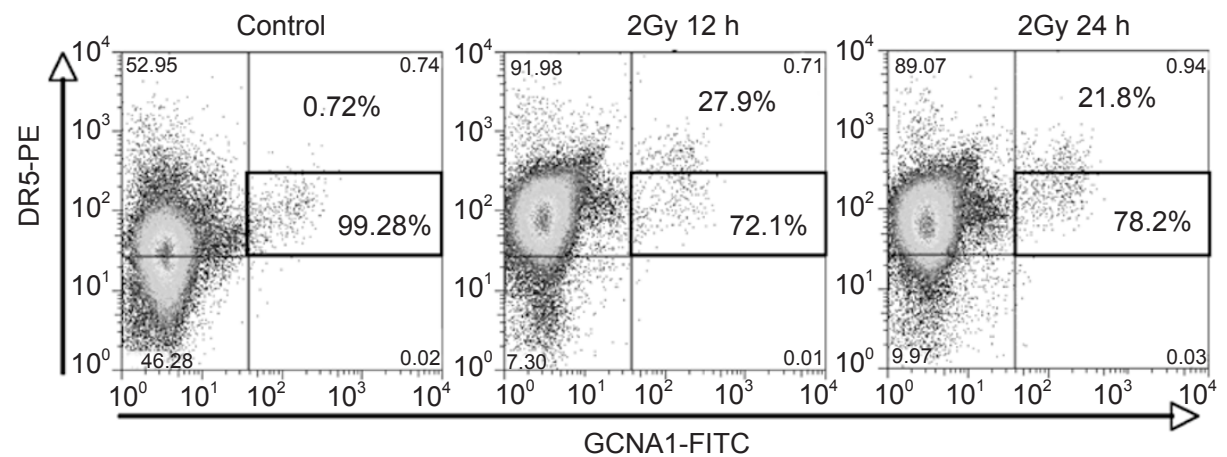

Figure 6 DR5 protein expression at the gonocyte surface after irradiation. Representative flow cytometric analysis of DR5 expression in cell suspensions prepared from testis of 1-day-old NMRI mice 12 and $24 \mathrm{~h}$ after 2 Gy of $\mathrm{Y}$-irradiation. The vertical axis shows phycoerythrin fluorescence corresponding to the DR5 labelling. Percentages of DR5-expressing cells are calculated by taking into account the background labelling (baseline defined by isotypic control). The horizontal axis shows FITC fluorescence corresponding to GCNA1 labelling, a marker of germ cells. The baseline was determined by taking into account the background labelling (baseline defined by isotypic control). The gate represents the fluorescent level of the gonocyte control population. Four independent experiments were performed, and at least 1000 GCNA1-positive cells were analysed.

Control

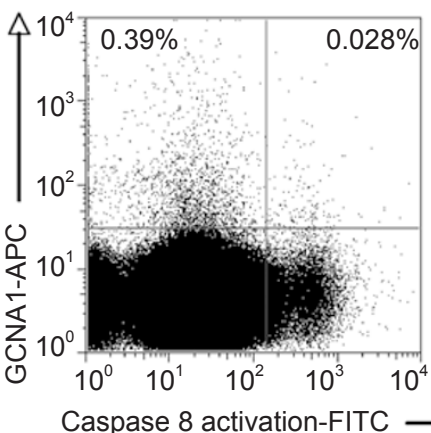

$2 \mathrm{~Gy} 12 \mathrm{~h}$

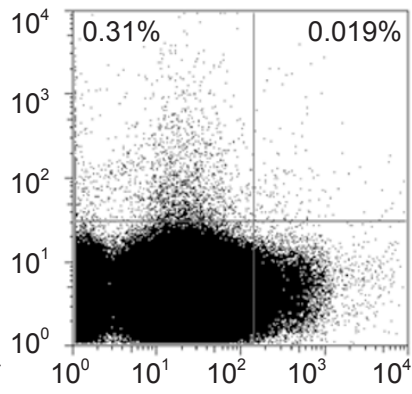

$2 \mathrm{~Gy} 24 \mathrm{~h}$

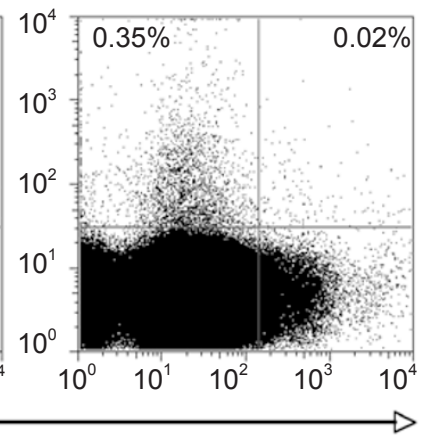

Figure 7 Analysis of caspase 8 activation in gonocytes after irradiation. Representative flow cytometric analysis of caspase 8 activation performed 12 and $24 \mathrm{~h}$ after irradiation. The vertical axis shows allophycocyanin fluorescence corresponding to the GCNA1 labelling, a specific marker of germ cells. The horizontal axis shows FITC fluorescence corresponding to caspase 8 activation. Percentages of gonocytes positive for activated caspase 8 were calculated by taking into account the background labelling (baseline defined by isotypic control). At least 1000 GCNA1-positive cells were analysed.

level after irradiation (not shown). Moreover, western blotting performed on whole testicular cells showed no change in the c-FLIP protein level (Supplementary information, Figure S2), indicating no regulation of c-FLIP expression after irradiation. Taken together, these results suggest no involvement of the extrinsic pathway in radiation-induced apoptosis in gonocytes.

Caspase 9 is activated in gonocytes in response to cytochrome $c$ release after $\gamma$-radiation

We showed that p53 target genes involved in the intrinsic pathway, such as Puma and Noxa, were upregulated in response to radiation exposure. To explore the involvement of this pathway, we investigated cytochrome $c$ release (Figure 8A) and caspase 9 cleavage (Figure 8B) after irradiation in gonocytes.

Cytochrome $c$ release was studied by flow cytometry, 7, 12 and $24 \mathrm{~h}$ after radiation exposure. No release was observed at 7 and $24 \mathrm{~h}$ after irradiation (not shown). Whereas, on average, $13.6 \% \pm 1.6 \%$ of germ cells were negative for cytochrome $c$ in NMRI control mice, we observed an increase of up to $22.5 \% \pm 1.8 \%$ of cytochrome $c$-negative gonocytes $12 \mathrm{~h}$ after irradiation $(P<0.05 ; n=$ 5 ), indicating the release of cytochrome $c$ from gonocyte mitochondria (the results of one such experiment are shown in Figure 8A).

Moreover, a study of the caspase 9 cleavage showed activation of the enzyme with a maximum level observed 
A

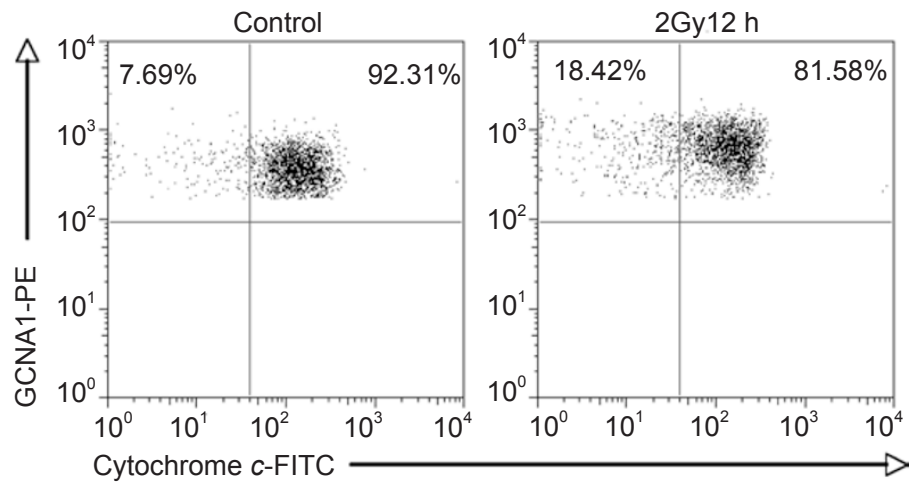

B

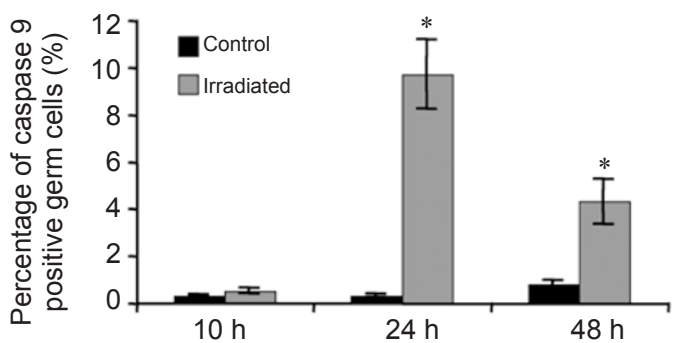

Figure 8 Analysis of cytochrome $c$ release and percentage of cleaved caspase 9-positive gonocytes after irradiation. (A) Representative flow cytometric analysis of cytochrome $c$ release performed $12 \mathrm{~h}$ after irradiation. The vertical axis shows phycoerythrin fluorescence corresponding to the GCNA1 labelling, a specific marker of germ cells. The horizontal axis shows FITC fluorescence corresponding to cytochrome $c$ staining. Gonocytes become negative for cytochrome $c$ when it is released. Percentages of gonocytes positive for cytochrome $c$ were calculated by taking into account the background labelling (baseline defined by isotypic control). At least 1000 GCNA1-positive cells were analysed. (B) Analysis of cleaved caspase 9-positive germ-cell percentage. Means \pm SEM of at least three animals are presented per experimental condition. Each time point (grey bar) is compared with the appropriate control (black bar) (i.e., $1 \mathrm{dpp}+10 \mathrm{~h}, 1 \mathrm{dpp}+24 \mathrm{~h}$, etc.). Significant differences from the control are indicated $(* P<0.05)$.

at $24 \mathrm{~h}$ after irradiation $(P<0.05$ against the control $)$ (Figure 8B). The percentage of gonocytes positive for cleaved caspase 9 rapidly decreased between 24 and $48 \mathrm{~h}$ $(P<0.05)$, but remained higher than that in the control $(P$ $<0.05)$. Taken together, these results suggest an involvement of the intrinsic pathway in radiation-induced apoptosis of gonocytes.

Validation of our results using KO mice study: the intrinsic pathway is the major one involved in gonocyte apoptosis

To validate our findings regarding the involvement of the two apoptotic pathways, we studied the effects of irradiation on Trail and Puma knockout (KO) mice (Figure 9).

Gonocytes, which are quiescent during late foetal life, start proliferating again after birth. It has been shown that no radiation-induced apoptosis occurs during the quiescent period, but rather it occurs after gonocytes re-enter the cell cycle [25]. In C57BL/6J mice, gonocytes resume mitosis one day later compared with those in NMRI mice (our lab, unpublished data), suggesting that gonocyte ap- optosis in C57BL/6J mice might be delayed. In contrast to the NMRI strain, no significant decrease in the germcell number was found $24 \mathrm{~h}$ after irradiation $(P=0.18)$ in C57BL/6J mice (not shown). However, C57BL/6J mice showed a decrease in the germ-cell number at the 48-h time point after irradiation.

Deficiency of Trail, which is the only known ligand for DR5 in the mouse [41], had no effect on the germ-cell number in $\mathrm{C} 57 \mathrm{BL} / 6 \mathrm{~J}$ control mice $(P=0.56)$. However, testes of irradiated $\mathrm{KO}$ mice exhibited more gonocytes than did that in the irradiated wild-type (WT) mice $(P<$ 0.05), suggesting that less apoptosis occurs in Trail KO mice (loss of $73 \%$ of gonocytes) (Figure 9A). Surprisingly, the percentage of gonocytes positive for cleaved caspase 3 (Figure 9B) and 9 (Figure 9C) was the same in irradiated WT and Trail KO mice. However, we found a significant decrease in the percentage of ISEL-positive cells in Trail KO compared with that in irradiated WT mice $(P<0.05)$ (Figure 9D). Since caspase activation was not modified and the differences in germ-cell numbers and the percentage of ISEL-positive germ cells were 
A

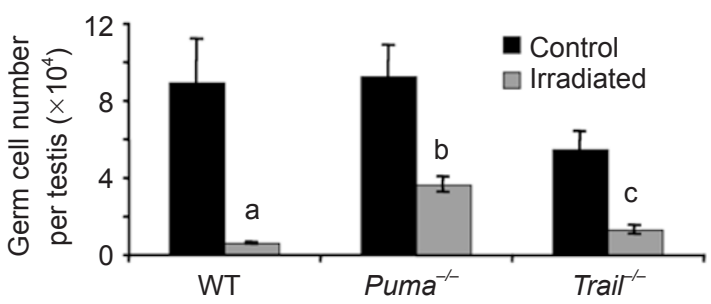

B

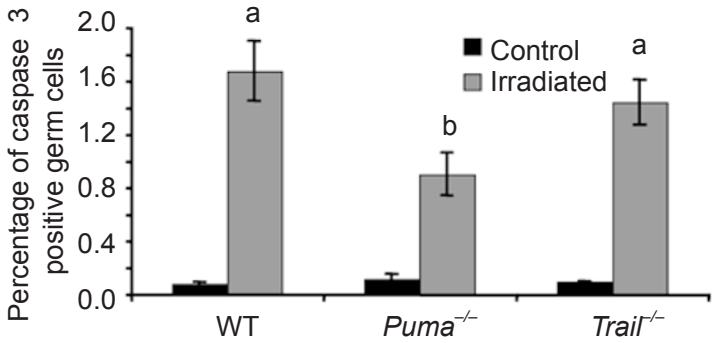

C

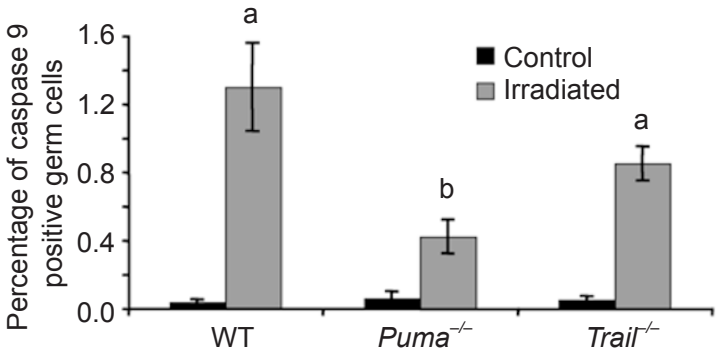

$\mathrm{D}$

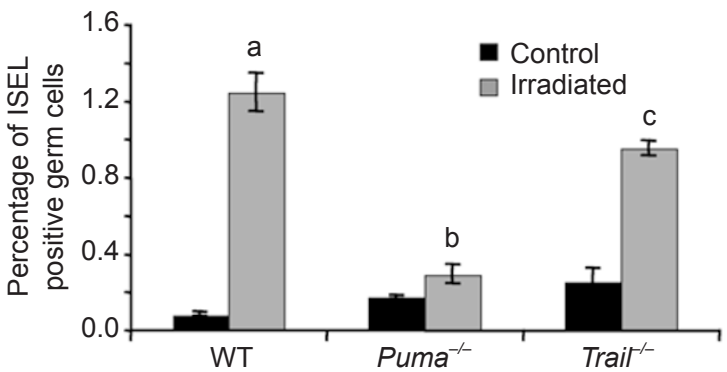

Figure 9 Trail and Puma knock-out mouse study. Two-day-old WT C57BL/6J and KO mice were irradiated at a dose of $2 \mathrm{~Gy}$ and killed $48 \mathrm{~h}$ later. Results are presented as means \pm SEM of 4 or 5 (KO mice) to 6 (WT) animals. (A) Analysis of germcell number per testis. (B) Analysis of cleaved caspase 3-positive gonocyte percentage. (C) Analysis of cleaved caspase 9-positive gonocyte percentage. (D) Analysis of ISEL-positive gonocyte percentage. Counts were performed after immunohistochemical staining. Grey bars represent irradiated conditions and black bars the appropriate controls. All irradiated conditions were significantly different from control $(P<0.05)$. Superscripts are different when values between irradiated conditions are significantly different $(P<0.05)$. little between WT and Trail KO mice, we suggest that the TRAIL/DR5 pathway had only a minor effect.

As with Trail KO mice, deficiency of Puma did not affect germ-cell numbers compared with that in the control $(P=0.9)$, but significantly decreased radiation-induced gonocyte death (loss of $61 \%$ of gonocytes) $(P=0.016)$ (Figure 9A). Moreover, the percentage of gonocytes positive for cleaved caspase 3 (Figure 9B), cleaved caspase 9 (Figure 9C) and ISEL (Figure 9D) was significantly decreased in irradiated $\mathrm{KO}$ mice compared with that in irradiated WT mice $(P<0.02)$.

Taken together, these results show that PUMA is of major importance in triggering gonocyte death in response to genotoxic stress.

\section{Discussion}

The aim of this study was to determine the apoptotic pathways activated in the precursors of spermatogonial stem cells (the gonocytes) after genotoxic stress. We show here that caspases are activated, in particular caspase 9, which is involved in the intrinsic pathway. In contrast, lack of caspase 8 activation suggests that somatic cell environment injury does not participate in gonocyte death through the extrinsic pathway. PUMA seems to be a critical regulator of the radiation-induced apoptotic response of gonocytes, whereas its role is minor in physiological apoptosis.

Apoptosis induced in germ cells has been shown to be caspase-dependent, regardless of the differentiation stage of the germ cells or of the stimulus [22, 23]. Our results show that this likely also holds true for gonocytes after genotoxic stress, since their death is correlated with caspase 3 activation. However, apoptosis is not completely abolished, and residual caspase 3 activation could be explained by the partial inhibition of z-VAD, which was injected in limited quantity, and/or by poor accessibility to the target tissue. Another possibility for gonocyte death would be the activation of a caspase-independent pathway. However, although gonocytes do express AIF, we did not observe any translocation of this protein from the cytoplasm into the nucleus after irradiation, even after z-VAD-fmk treatment. This suggests that AIF may not be involved in gonocyte radiation-induced death as in adult germ cells [42], and does not compensate for the inhibition of caspases. Even though we cannot exclude that our immunohistochemical approach may not be sensitive enough to highlight possible small amounts of AIF in the nucleus of irradiated gonocytes, caspase-independent apoptosis is unlikely to be a major player.

Members of the p53 family have been shown to be involved in genotoxic stress-induced germ cell death $[27$, 
$28,43,44]$. In contrast to oocytes [44], p63 (also known as Trp63) has not been found to be involved in radiationinduced cell death of foetal gonocytes $[45,46]$. This seems to be confirmed in neonatal gonocytes, in which p63a mRNA (the main isoform in the testis at the age studied) is not deregulated after irradiation (Supplementary information, Figure S3). P73 (also known as TRP73) is localised in the cytoplasm of foetal [45] and neonatal (Supplementary information, Figure S4) gonocytes. As has been shown in adult spermatogonia [43], P73 is not relocated in the nucleus of gonocytes after irradiation (Supplementary information, Figure S4). However, this does not exclude cytoplasmic P73 from having a role in response to genotoxic stress, as described in the adult [43]. It has been shown that radiation-induced apoptosis is dependent on WT $p 53$ in proliferating adult spermatogonia. Indeed, $p 53 \mathrm{KO}$ mice exhibit negligible degeneration in differentiating spermatogonia after irradiation compared with WT mice $[27,28]$. We showed phospho-p53 staining in the nuclei of gonocytes after irradiation and induction of p53-targeted apoptotic genes in the testis, suggesting a role of p53 in gonocyte apoptosis. Moreover, injection of pifithrin $\alpha$ in irradiated mice decreases caspase 3 activation and p53-dependent gene transcription, confirming the involvement of $\mathrm{p} 53$.

Although we found that both the expression of DR5 and the receptor number at the cell surface were upregulated after irradiation, no caspase 8 activation was detected. We asked whether c-Flip may be involved in the regulation of the response to radiation. c-FLIP is exclusively expressed in gonocytes [40, 47], and is known to protect germ cells from FAS-mediated apoptosis in the foetal mouse [47]. We found that c-Flip was not modified at either the mRNA or the protein level in our model after irradiation. Therefore, we propose that the constitutive level of c-FLIP is sufficient in gonocytes to inhibit caspase 8 activation after irradiation. These results suggest that the extrinsic pathway is not involved in response to neonatal germ-cell injury, and that the somatic environment may impede germ-cell differentiation [48] rather than participate in their death. Trail KO mice show a decrease in germ-cell death compared with that in WT mice after irradiation, but no change in caspase 3 activation due to the intrinsic pathway activation. Nevertheless, the difference in germ-cell loss between irradiated control and Trail KO mice suggests that $20 \%$ of germ-cell death depends on TRAIL/DR5 pathway activation. These results confirm a minor involvement of the TRAIL/DR5 pathway, which could act through a caspase-independent mechanism [49]. This would explain the absence of caspase 8 activation after irradiation in WT mice, whereas the gonocyte number is still significantly reduced in ir- radiated Trail $\mathrm{KO}$ mice.

Several proteins involved in the intrinsic pathway have been shown to be involved in physiological apoptosis in the mouse testis $[16,19,20]$. Moreover, it has been shown in human foetal testis that irradiation enhances both Bax and Puma transcription [50]. In accordance with this, we found an increase in Bax, Noxa (also known as Pmaip 1) and Puma mRNA in the neonatal mouse testis, suggesting mitochondrial pathway activation. Mitochondrial cytochrome $c$ release correlated with caspase 9 cleavage. The $\mathrm{BH} 3$-only proteins are known to regulate apoptosis positively $[16,19,20,51]$. In contrast to NOXA, which can only bind MCL1 [52], PUMA can bind to all anti-apoptotic proteins and directly activates BAX [53]. PUMA has been shown to be involved in radiation-induced apoptosis of numerous cell type 35 and is central to its regulation. PUMA has been shown to couple the nuclear and cytoplasmic pro-apoptotic functions of p53 [54]. In this model, p53 accumulates in the nucleus after apoptosis induction to directly regulate the expression of pro-apoptotic genes such as Puma. At the same time, p53 accumulates in the cytoplasm where it is sequestered by BCL- $\mathrm{X}_{\mathrm{L}}$. PUMA could then bind to BCL$\mathrm{X}_{\mathrm{L}}$, allowing the release of $\mathrm{p} 53$, which in turn could activate BAX to induce cytochrome $c$ release. Puma KO mice exhibit normal development and fertility in control conditions [55], indicating that PUMA is not necessary for physiological apoptosis. However, we found significant germ-cell protection against irradiation in these mice, suggesting that PUMA is involved in genotoxic stress-induced apoptosis in gonocytes. Such a specific role in radiation-induced apoptosis has been shown for p53 [27, 28]. Interestingly, p53 accumulates at the mitochondria in adult testis after in vivo irradiation [56]. We propose that PUMA and p53 are required in genotoxic stress conditions and could act together to induce gonocyte apoptosis. Furthermore, gonocytes of Puma KO mice are not fully protected against radiation-induced apoptosis, and caspase 9 is activated, suggesting a role for another protein in the regulation of the intrinsic pathway. Michalak et al. [57] have recently shown that deficiency of both Puma and Noxa protects thymocytes against irradiation better than does Puma $\mathrm{KO}$ alone. Taking their findings together with our data, we propose that NOXA could be involved in the gonocyte response to genotoxic stress. In addition, we cannot exclude the involvement of non-apoptotic cell death activation.

In conclusion, we demonstrate that, although radiation injures both somatic and germ cells, precursors of spermatogonial stem cells are killed by radiation without any major contribution of the somatic compartment. Moreover, we show that PUMA, which is not involved in 
natural germ cell apoptosis, is critical in the maintenance of genomic integrity in spermatogonial stem cell precursors.

\section{Materials and Methods}

Mice, irradiation and pan-caspase inhibitor (z-VAD-fmk) and pifithrin $\alpha$ in vivo treatments

The mice used were homozygous transgenic mice (Trail ${ }^{\llcorner}$and Puma $^{--}$) on a C57BL/6J background, NMRI and C57BL/6J WT mice. The mice were bred and maintained according to the French regulations (Ministry of Agriculture-decree 87-848) in our animal facilities, which are accredited by the veterinary inspectorate (A92-032-02).

One-day-old NMRI mice were whole-body exposed to $\gamma$-rays from a ${ }^{137} \mathrm{Cs}$ source (IBL 637; CIS Bio International, France) at a dose of $2 \mathrm{~Gy}$, and killed 10, 24, 48 or $96 \mathrm{~h}$ later. Because of differences in the timing of germ-cell development between NMRI and C57BL/6J mice [58], NMRI mice were irradiated at $1 \mathrm{dpp}$ and C57BL/6J at $2 \mathrm{dpp}$.

Z-VAD-fmk (Pharmingen, USA) $(100 \mathrm{mg} / \mathrm{kg})$ and pifithrin $\alpha$ (Sigma-Aldrich, France) $(10 \mathrm{mg} / \mathrm{kg})$ were injected intraperitoneally $1 \mathrm{~h}$ before irradiation and the mice were killed $24 \mathrm{~h}$ later. DMSO (Sigma) was injected as control at the same concentration. The control and treated mice that were analysed were from the same litter.

\section{Immunohistochemistry and cell counting}

Testes were fixed in $4 \%$ phosphate buffered formaldehyde (Sigma) overnight at $4{ }^{\circ} \mathrm{C}$, embedded in paraffin and $5 \mu \mathrm{m} \mathrm{sec}$ tions were cut. The sections were mounted on starfrost slides and the paraffin was removed in toluene. The sections were rehydrated in a graded series of alcohols. Immunohistochemistry was performed as previously described $[46,50,59,60]$. Briefly, slides were heated in a $0.01 \mathrm{M}$ sodium citrate solution $\mathrm{pH} 6$ in a microwave oven for $5 \mathrm{~min}$ at $900 \mathrm{~W}$, and then for $3 \mathrm{~min}$ at $600 \mathrm{~W}$. After cooling, sections were incubated in $3 \% \mathrm{H}_{2} \mathrm{O}_{2}$ in water for $15 \mathrm{~min}$. Blocking of non-specific antigenic sites was performed in 5\% BSA in PBS. The slides were then incubated with rabbit polyclonal antibodies against cleaved caspase 3 (1:100; Cell Signaling Technology, USA), cleaved caspase 9 (1:100, Cell Signaling Technology), phospo(ser15)-p53 (1:50, Abcam, UK), AIF (1:100, Cell Signaling Technology) or P73 (1/50, Santa Cruz) in PBS/5\% BSA overnight at $4{ }^{\circ} \mathrm{C}$. Primary antibodies were detected after incubation with secondary biotinylated goat anti-rabbit $\operatorname{IgG}(1: 200$, Vector Laboratories, CA) for $30 \mathrm{~min}$ at room temperature, and the avidin-biotin-peroxidase complex (Vectastain Elite ABC kit, Vector Laboratories). Peroxidase activity was visualised using 3,3'diaminobenzidine and slides were washed in PBS for $10 \mathrm{~min}$. The second staining was performed using rabbit anti-MVH $(1: 500$, Abcam) or mouse anti-deleted in azoospermia-like (DAZL) (1:100, Serotec, UK) primary antibodies. The secondary antibodies used were the same as previously described, and bound antibodies were visualised using VIP substrate (Vector Laboratories). Sections were counterstained with haematoxylin. Negative controls were obtained by omitting the primary antibody.

Cleaved caspase 3/DAZL fluorescent immunostaining was performed as described above, except that both primary antibodies were incubated at the same time and visualised with Cy3-conju- gated donkey anti-rabbit IgG (1:800; Jackson ImmunoResearch Laboratories) and FITC-conjugated donkey anti-mouse $\operatorname{IgG}$ (1:50; Jackson ImmunoResearch Laboratories) for $1 \mathrm{~h}$ at room temperature. The sections were counterstained with DAPI. Fluorescent images were captured using an Olympus AX70 epifluorescence microscope equipped with a charge-coupled camera (Princeton Instruments) and IPLab software (Scanalytics).

For ISEL/MVH double staining, the slides were heated in a $0.01 \mathrm{M}$ sodium citrate as described above and incubated in 3\% $\mathrm{H}_{2} \mathrm{O}_{2}$ in $\mathrm{H}_{2} \mathrm{O}$ for 5 min. ISEL staining was performed using the Apoptag peroxidase kit (MP Biomedicals), according to the manufacturer's protocol. Briefly, the sections were incubated with Working Strength TdT enzyme for $1 \mathrm{~h}$ at $37{ }^{\circ} \mathrm{C}$. The reaction was stopped with Stop/Wash Buffer for 10 min and the slides were incubated with an anti-digoxigenin peroxidase conjugate for $30 \mathrm{~min}$ at room temperature. Peroxidase activity was visualised using 3,3'diaminobenzidine and the slides were washed in PBS for $10 \mathrm{~min}$. MVH staining was then performed as described above.

Germ cells were counted in one of 20 sections that were equidistantly distributed along the testis. All counts were done with Histolab software (Microvision Instruments, France). We used the Abercrombie formula to correct for any double counting due to single cells appearing in two successive sections [61].

\section{Testicular cell preparation}

Testes were extirpated and albuginea was removed. Decapsulated testes were cut into pieces and incubated in HBSS with $10 \mathrm{mg} /$ $\mathrm{ml}$ collagenase I (Serva, Germany) and with $0.2 \mathrm{mg} / \mathrm{ml}$ DNase I (Sigma) for $15 \mathrm{~min}$ at $37^{\circ} \mathrm{C}$ in a shaking water bath. Every $5 \mathrm{~min}$, testis fragments were resuspended with a pipette. After complete digestion, the cells were centrifuged for $5 \mathrm{~min}$ at $400 \times g$ and resuspended in HBSS.

\section{Germ-cell enrichment}

Cells were resuspended in an extraction buffer (HBSS, $20 \mathrm{mM}$ Hepes, $6.6 \mathrm{mM}$ sodium pyruvate and $0.5 \%$ FCS) and incubated with a rat anti-TACSTD1 antibody (Pharmingen) at $4{ }^{\circ} \mathrm{C}$ for 20 min. Following two washes, the cells were incubated with antirat microbeads (Miltenyi Biotech, Germany) at $4{ }^{\circ} \mathrm{C}$ for $20 \mathrm{~min}$. The fractions enriched for TACSTD1-positive cells were obtained using a MACS separator, according to the manufacturer's instructions (Miltenyi Biotech). Since at $1 \mathrm{dpp}$, germ cells represent only $0.5 \%$ of the testicular cell population, enrichment of gonocytes allowed us to obtain fractions with $5-10 \%$ of germ cells.

\section{Reverse transcription and real-time polymerase chain reac- tion}

Total RNA was extracted from enriched germ-cell preparations using the RNeasy mini kit (Qiagen, France), according to the manufacturer's instruction. RNAs were quantified by measuring the optical density at $260 \mathrm{~nm}$, and $500 \mathrm{ng}$ were reverse-transcribed using the Omniscript RT kit (Qiagen) according to the manufacturer's instructions.

Real-time PCR was performed using the ABI Prism 7000 Sequence Detection system (Applied Biosystems, France) according to the manufacturer's instructions.

The following probes were used: c-Flip, Mm01255579_m1; and Actb, Mm00607939_s1 (designed on request by Applied Biosystems).

Primers for Dr5 were forward 5'-CTG TGC ATT CGT CTC 
TCT TGG-3' and reverse 5'-TGA GTC GTT TCC GTT TAC CG3', for Fas forward 5'-TCT GCG ATG AAG AGC ATG GTT-3' and reverse 5'-GCA GCG AAC ACA GTG TTC ACA-3', for Bax forward 5'-TCA AGG CCC TGT GCA CTA A-3' and reverse 5'TGA GGA CTC CAG CCA CAA A-3', for $B c l-x_{L}$ forward 5'-GAT GCA GGT ATT GGT GAG TCG G-3' and reverse 5'-ATC CAC AAA AGT GTC CCA GCC-3', for Puma forward 5'-CAC CCC ATC GCC TCC TTT CT-3' and reverse 5'-GGA AGG GGC GCG GAC TGT CG-3', for Noxa forward 5'-TGG AGT GCA CCG GAC ATA ACT-3', for Trp53 forward 5'-TGT AAT AGC TCC TGC ATG GGG-3' and reverse 5'-TTC TGT ACG GCG GTC TCT CCC-3', for $p 63 \alpha$ forward 5'-GTT CAC CAC GGG TCT CAC-3' and reverse 5'-TTC TCC TCA CCT CCT CAT CTC C-3'. $M v h$ primers, used as reference, were forward 5'-GAA GAA ATC CAG AGG TTG GC-3' and reverse 5'-GAA GGA TCG TCT GCT GAA CA-3'. All primers were designed to avoid amplification of contaminant DNA. c-Flip and Actb mRNAs were quantified using the TaqMan Gene Expression Master Mix, and the other mRNAs using SYBR Green Universal PCR Master Mix (Applied Biosystems) in a total volume of $20 \mu \mathrm{l}$. Samples were heated for $10 \mathrm{~min}$ at $95{ }^{\circ} \mathrm{C}$, followed by 40 cycles of $15 \mathrm{~s}$ at $95^{\circ} \mathrm{C}$, then for $1 \mathrm{~min}$ at $60{ }^{\circ} \mathrm{C}$. Each sample was run in duplicate.

DR5/GCNA1 (germ-cell nuclear antigen) staining for fluorescence-activated cell sorter (FACS) analysis

The cell suspension was adjusted to $10^{6}$ cells $/ \mathrm{ml}$ and incubated with a phycoerythrin (PE)-conjugated anti-DR5 antibody (Pharmingen) for $15 \mathrm{~min}$ at $4{ }^{\circ} \mathrm{C}$. The cells were fixed and permeabilised with a Cytofix/Cytoperm buffer (Becton Dickinson, USA) for $20 \mathrm{~min}$ at room temperature. Then cells were then permeabilised with the Cytoperm plus buffer (Becton Dickinson) for $10 \mathrm{~min}$ at $4{ }^{\circ} \mathrm{C}$ and fixed again for $5 \mathrm{~min}$ at $4{ }^{\circ} \mathrm{C}$. Finally, the cells were incubated with a rat anti-GCNA1 antibody (generously provided by Dr G Enders) (1:50) in a final volume of $50 \mathrm{ml}$. Bound antibodies were visualised with $1 \mathrm{mg} / 10^{6}$ cells of FITC-conjugated antirat $\operatorname{IgM}$ (Pharmingen) for $20 \mathrm{~min}$ at $4{ }^{\circ} \mathrm{C}$. DNA was counterstained with Hoechst $(5 \mathrm{mg} / \mathrm{ml})$ and the cells were analysed in a FACS (Becton Dickinson). Controls were obtained by omitting the primary antibody or by replacing it by its isotype.

\section{Western blotting}

Total testicular cell lysates were obtained by homogenisation on ice of 3 testes in $50 \mu \mathrm{l}$ of a cell lysis buffer $(20 \mathrm{mM}$ Tris- $\mathrm{HCl}$ $\mathrm{pH} 8,150 \mathrm{mM} \mathrm{NaCl}, 5 \mathrm{mM}$ EDTA, $1 \%$ Triton, $1 \mathrm{mM} \mathrm{Na} \mathrm{VO}_{4}$, $10 \mathrm{mM} \mathrm{NaF}, 10 \mathrm{mM} \beta$-glycerophosphate, complete mini protease inhibitor cocktail [Roche, Switzerland] and $0.1 \%$ SDS). After centrifugation at $11000 \times g$ for $15 \mathrm{~min}$ at $4{ }^{\circ} \mathrm{C}$, a supernatant containing proteins was used for further analysis.

Protein concentration was determined by the Bradford method and $50 \mu \mathrm{g}$ was resolved in $12 \%$ SDS-polyacrylamide gel and transferred to nitrocellulose membranes (Hybond C, Amersham, England). The nitrocellulose membranes were saturated with nonfat dry milk (Bio-Rad, USA) and incubated with a c-FLIP polyclonal antibody (1:500, Upstate, USA). The secondary antibody was horseradish peroxidase-conjugated anti-rabbit (Jackson ImmunoResearch, USA). Protein-antibody complex detection was performed by enhanced chemiluminescence (ECL, Amersham). Membranes were stripped before detection of MVH (1:750, Abcam) and used as reference. The relative levels of c-FLIP were determined by integrated optical density using Biocapt software
(Vilber Lourmat, France).

\section{Active caspase 8 detection by flow cytometry}

The cell suspension was adjusted to $10^{6}$ cells $/ \mathrm{ml}$. Staining was performed according to the manufacturer's protocol (Vybrant ${ }^{\circledR}$ FAM Caspase-8 Essay Kit, Molecular Probes, France). Briefly, the cells were incubated for $1 \mathrm{~h}$ with FLICA $^{\mathrm{TM}}$, a fluorescent inhibitor of activated caspase 8 , and fixed with a fixative solution containing methanol and formaldehyde for $15 \mathrm{~min}$ at $4{ }^{\circ} \mathrm{C}$. Germ cells were then stained with anti-rat GCNA1 (1:50) for $30 \mathrm{~min}$ at room temperature. The primary antibody was visualised with an allophycocyanin-conjugated anti-rat antibody (Jackson Immunoresearch) for 30 min at $4{ }^{\circ} \mathrm{C}$. The cells were analysed in a FACS (Becton Dickinson). The positive control was obtained from mouse thymocytes after 5 Gy of irradiation combined with an intravenous injection of $10 \mathrm{mg}$ of a Fas antibody (Clone Jo2) (Pharmingen).

\section{Cytochrome c/GCNA1 double staining for FACS analysis}

The cell suspension was adjusted to $4 \times 10^{6}$ cells $/ \mathrm{ml}$. Staining was performed according to the manufacturer's protocol (InnoCyte $^{\text {TM }}$ Flow Cytometric Cytochrome $c$ Release Kit, Calbiochem, USA). Briefly, the cells were permeabilised and fixed. Non-specific sites were blocked for $1 \mathrm{~h}$ and the cells were then incubated with an anti-cytochrome $c$ antibody, which was visualised with an FITC-conjugated secondary antibody. Germ cells were stained with anti-rat GCNA1 (1:50) for $30 \mathrm{~min}$ at room temperature. GCNA1 was visualised with a PE-conjugated anti-rat antibody (Jackson Immunoresearch) for $30 \mathrm{~min}$ at $4{ }^{\circ} \mathrm{C}$. The cells were analysed in a FACS (Becton Dickinson).

\section{Statistical analysis}

Results are presented as means \pm SEM. Statistical analyses were performed using either Student's $t$-test or the alternate Welch $t$-test, when SDs are different, or the non-parametric Mann-Whitney $U$-test. In all cases, the level of statistical significance was set at $P<0.05$

\section{Acknowledgements}

This work was supported by Electricité de France (EDF). A Forand holds a fellowship from l'Association pour la Recherche contre le Cancer (ARC). We thank V Neuville and C Joubert for animal care. Trail knock-out mice were provided by Amgen Inc. Puma knock-out mice were kindly provided by A Villunger (Innsbruck, Austria). We are also grateful to P Fouchet for assistance in flow cytometric analysis. We thank M Coureuil and I Allemand for sharing materials and unpublished data.

\section{References}

1 Wyllie AH, Kerr JF, Currie AR. Cell death: the significance of apoptosis. Int Rev Cytol 1980; 68:251-306.

2 Muzio M. Signalling by proteolysis: death receptors induce apoptosis. Int J Clin Lab Res 1998; 28:141-147.

3 Boldin MP, Goncharov TM, Goltsev YV, Wallach D. Involvement of MACH, a novel MORT1/FADD-interacting protease, in Fas/APO-1- and TNF receptor-induced cell death. Cell 1996; 85:803-815.

4 Muzio M, Chinnaiyan AM, Kischkel FC, et al. FLICE, a nov- 
el FADD-homologous ICE/CED-3-like protease, is recruited to the CD95 (Fas/APO-1) death--inducing signaling complex. Cell 1996; 85:817-827.

5 Chen M, Orozco A, Spencer DM, Wang J. Activation of initiator caspases through a stable dimeric intermediate. $J$ Biol Chem 2002; 277:50761-50767.

6 Muzio M, Stockwell BR, Stennicke HR, Salvesen GS, Dixit VM. An induced proximity model for caspase- 8 activation. $J$ Biol Chem 1998; 273:2926-2930.

7 Muzio M, Salvesen GS, Dixit VM. FLICE induced apoptosis in a cell-free system. Cleavage of caspase zymogens. $J$ Biol Chem 1997; 272:2952-2956.

8 Irmler M, Thome M, Hahne M, et al. Inhibition of death receptor signals by cellular FLIP. Nature 1997; 388:190-195.

9 Scaffidi C, Schmitz I, Krammer PH, Peter ME. The role of cFLIP in modulation of CD95-induced apoptosis. J Biol Chem 1999; 274:1541-1548.

10 Chang DW, Xing Z, Pan Y, et al. c-FLIP(L) is a dual function regulator for caspase-8 activation and CD95-mediated apoptosis. EMBO J 2002; 21:3704-3714.

11 Gross A, Jockel J, Wei MC, Korsmeyer SJ. Enforced dimerization of BAX results in its translocation, mitochondrial dysfunction and apoptosis. EMBOJ 1998; 17:3878-3885.

12 Srinivasula SM, Ahmad M, Fernandes-Alnemri T, Alnemri ES. Autoactivation of procaspase-9 by Apaf-1-mediated oligomerization. Mol Cell 1998; 1:949-957.

13 Michalak E, Villunger A, Erlacher M, Strasser A. Death squads enlisted by the tumour suppressor p53. Biochem Biophys Res Commun 2005; 331:786-798.

14 Susin SA, Lorenzo HK, Zamzami N, et al. Molecular characterization of mitochondrial apoptosis-inducing factor. Nature 1999; 397:441-446.

15 Ye H, Cande C, Stephanou NC, et al. DNA binding is required for the apoptogenic action of apoptosis inducing factor. Nat Struct Biol 2002; 9:680-684.

16 Rodriguez I, Ody C, Araki K, Garcia I, Vassalli P. An early and massive wave of germinal cell apoptosis is required for the development of functional spermatogenesis. EMBO J 1997; 16:2262-2270.

17 de Rooij DG, Grootegoed JA. Spermatogonial stem cells. Curr Opin Cell Biol 1998; 10:694-701.

18 Wang RA, Nakane PK, Koji T. Autonomous cell death of mouse male germ cells during fetal and postnatal period. Biol Reprod 1998; 58:1250-1256.

19 Furuchi T, Masuko K, Nishimune Y, Obinata M, Matsui Y. Inhibition of testicular germ cell apoptosis and differentiation in mice misexpressing Bcl-2 in spermatogonia. Development 1996; 122:1703-1709.

20 Knudson CM, Tung KS, Tourtellotte WG, Brown GA, Korsmeyer SJ. Bax-deficient mice with lymphoid hyperplasia and male germ cell death. Science 1995; 270:96-99.

21 Lizama C, Alfaro I, Reyes JG, Moreno RD. Up-regulation of CD95 (Apo-1/Fas) is associated with spermatocyte apoptosis during the first round of spermatogenesis in the rat. Apoptosis 2007; 12:499-512.

22 Lee J, Richburg JH, Shipp EB, Meistrich ML, Boekelheide K. The Fas system, a regulator of testicular germ cell apoptosis, is differentially up-regulated in Sertoli cell versus germ cell injury of the testis. Endocrinology 1999; 140:852-858.
23 Hikim AP, Lue Y, Yamamoto CM, et al. Key apoptotic pathways for heat-induced programmed germ cell death in the testis. Endocrinology 2003; 144:3167-3175.

24 Hasegawa M, Wilson G, Russell LD, Meistrich ML. Radiation-induced cell death in the mouse testis: relationship to apoptosis. Radiat Res 1997; 147:457-467.

25 Moreno SG, Dutrillaux B, Coffigny H. High sensitivity of rat foetal germ cells to low dose-rate irradiation. Int J Radiat Biol 2001; 77:529-538.

26 Vergouwen RP, Huiskamp R, Bas RJ, et al. Radiosensitivity of testicular cells in the fetal mouse. Radiat Res 1995; 141:6673.

27 Beumer TL, Roepers-Gajadien HL, Gademan IS, et al. The role of the tumor suppressor p53 in spermatogenesis. Cell Death Differ 1998; 5:669-677.

28 Hasegawa M, Zhang Y, Niibe H, Terry NH, Meistrich ML. Resistance of differentiating spermatogonia to radiationinduced apoptosis and loss in p53-deficient mice. Radiat Res 1998; 149:263-270.

29 Embree-Ku M, Venturini D, Boekelheide K. Fas is involved in the p53-dependent apoptotic response to ionizing radiation in mouse testis. Biol Reprod 2002; 66:1456-1461.

30 Grataroli R, Vindrieux D, Gougeon A, Benahmed M. Expression of tumor necrosis factor-alpha-related apoptosis-inducing ligand and its receptors in rat testis during development. Biol Reprod 2002; 66:1707-1715.

31 Grataroli R, Vindrieux D, Selva J, et al. Characterization of tumour necrosis factor-alpha-related apoptosis-inducing ligand and its receptors in the adult human testis. Mol Hum Reprod 2004; 10:123-128.

32 McKee CM, Ye Y, Richburg JH. Testicular germ cell sensitivity to TRAIL-induced apoptosis is dependent upon p53 expression and is synergistically enhanced by DR5 agonistic antibody treatment. Apoptosis 2006; 11:2237-2250.

33 Selby PB. X-ray-induced specific-locus mutation rate in newborn male mice. Mutat Res 1973; 18:63-75.

34 Finnberg N, Gruber JJ, Fei P, et al. DR5 knockout mice are compromised in radiation-induced apoptosis. Mol Cell Biol 2005; 25:2000-2013.

35 Jeffers JR, Parganas E, Lee Y, et al. Puma is an essential mediator of p53-dependent and -independent apoptotic pathways. Cancer Cell 2003; 4:321-328.

36 Forand A, Fouchet P, Lahaye JB, Chicheportiche A, Habert $\mathrm{R}$, Bernardino-Sgherri J. Similarities and differences in the in vivo response of mouse neonatal gonocytes and spermatogonia to genotoxic stress. Biol Reprod 2009 Jan 14; [ DOI:10.1095/biolreprod.108.072884]

37 Komarov PG, Komarova EA, Kondratov RV, et al. A chemical inhibitor of $\mathrm{p} 53$ that protects mice from the side effects of cancer therapy. Science 1999; 285:1733-1737.

38 Ferber D. Cancer research. A new way to combat therapy side effects. Science 1999; 285:1651, 1653.

39 Hudson JM, Frade R, Bar-Eli M. Wild-type p53 regulates its own transcription in a cell-type specific manner. DNA Cell Biol 1995; 14:759-766.

40 Giampietri C, Petrungaro S, Coluccia P, et al. c-Flip(L) is expressed in undifferentiated mouse male germ cells. FEBS Lett 2006; 580:6109-6114.

41 Wu GS, Burns TF, Zhan Y, Alnemri ES, El-Deiry WS. Molec- 
ular cloning and functional analysis of the mouse homologue of the KILLER/DR5 tumor necrosis factor-related apoptosisinducing ligand (TRAIL) death receptor. Cancer Res 1999; 59:2770-2775.

42 Chater S, Amara S, Moussata D, et al. Differential effects of ionizing radiation and platinum-derivative chemotherapy on apoptotic pathways in testicular germ cells. Int J Radiat Biol 2007; 83:269-278.

43 Hamer G, Gademan IS, Kal HB, de Rooij DG. Role for c-Abl and p 73 in the radiation response of male germ cells. Oncogene 2001; 20:4298-4304.

44 Suh EK, Yang A, Kettenbach A, et al. p63 protects the female germ line during meiotic arrest. Nature 2006; 444:624-628.

45 Petre-Lazar B, Livera G, Moreno SG, et al. The role of p63 in germ cell apoptosis in the developing testis. J Cell Physiol 2007; 210:87-98.

46 Petre-Lazar B, Moreno SG, Livera G, et al. p63 expression pattern in foetal and neonatal gonocytes after irradiation and role in the resulting apoptosis by using p63 knockout mice. Int J Radiat Biol 2006; 82:771-780.

47 Giampietri C, Petrungaro S, Klinger FG, et al. c-Flip expression and function in fetal mouse gonocytes. Faseb J 2006; 20:124-126.

48 Zhang Z, Shao S, Meistrich ML. The radiation-induced block in spermatogonial differentiation is due to damage to the somatic environment, not the germ cells. J Cell Physiol 2007; 211:149-158.

49 Thon L, Mathieu S, Kabelitz D, Adam D. The murine TRAIL receptor signals caspase-independent cell death through ceramide. Exp Cell Res 2006; 312:3808-3821.

50 Lambrot R, Coffigny H, Pairault C, et al. High radiosensitivity of germ cells in human male fetus. J Clin Endocrinol Metab 2007; 92:2632-2639.

51 Cory S, Huang DC, Adams JM. The Bcl-2 family: roles in cell survival and oncogenesis. Oncogene 2003; 22:85908607.
52 Chen L, Willis SN, Wei A, et al. Differential targeting of prosurvival $\mathrm{Bcl}-2$ proteins by their $\mathrm{BH} 3$-only ligands allows complementary apoptotic function. Mol Cell 2005; 17:393403.

53 Kim H, Rafiuddin-Shah M, Tu HC, et al. Hierarchical regulation of mitochondrion-dependent apoptosis by BCL-2 subfamilies. Nat Cell Biol 2006; 8:1348-1358.

54 Chipuk JE, Bouchier-Hayes L, Kuwana T, Newmeyer DD, Green DR. PUMA couples the nuclear and cytoplasmic proapoptotic function of p53. Science 2005; 309:1732-1735.

55 Villunger A, Michalak EM, Coultas L, et al. p53- and druginduced apoptotic responses mediated by $\mathrm{BH} 3$-only proteins puma and noxa. Science 2003; 302:1036-1038.

56 Erster S, Mihara M, Kim RH, Petrenko O, Moll UM. In vivo mitochondrial p53 translocation triggers a rapid first wave of cell death in response to DNA damage that can precede p53 target gene activation. Mol Cell Biol 2004; 24:6728-6741.

57 Michalak EM, Villunger A, Adams JM, Strasser A. In several cell types tumour suppressor p53 induces apoptosis largely via Puma but Noxa can contribute. Cell Death Differ 2008; 15:1019-1029

58 Western PS, Miles DC, van den Bergen JA, Burton M, Sinclair AH. Dynamic regulation of mitotic arrest in fetal male germ cells. Stem Cells 2008; 26:339-347.

59 Delbes G, Levacher C, Pairault C, et al. Estrogen receptor beta-mediated inhibition of male germ cell line development in mice by endogenous estrogens during perinatal life. Endocrinology 2004; 145:3395-3403.

60 Hanoux V, Pairault C, Bakalska M, Habert R, Livera G. Caspase-2 involvement during ionizing radiation-induced oocyte death in the mouse ovary. Cell Death Differ 2007; 14:671681 .

61 Abercrombie M. Estimation of nuclear population from microtome sections. Anat Rec 1946; 94:338-348.

(Supplementary information is linked to the online version of the paper on the Cell Research website.) 